\title{
The recovery after Achilles tendon rupture: a protocol for a multicenter prospective cohort study
}

Olivier C. Dams ${ }^{1,2^{*}}$, Inge van den Akker-Scheek ${ }^{2}$, Ron L. Diercks², Klaus W. Wendt ${ }^{3}$, Eelke Bosma ${ }^{4}$, Tom M. van Raaiij, Arvid V. Munzebrock ${ }^{6}$, Wierd P. Zijlstra ${ }^{7}$, Johannes Zwerver ${ }^{1}$ and Inge H. F. Reininga ${ }^{3}$

\begin{abstract}
Background: Achilles tendon rupture (ATR) is a common sports injury, with a rising incidence and significant impairments. Due to the lack of treatment guidelines, there is no consensus about diagnostic methods, primary treatment (non-surgical or surgical) and rehabilitation. It is hypothesized that this lack of consensus and guidelines leads to sub-optimal recovery and higher societal costs.

The primary aim of this study is to give a broad insight into the recovery after ATR. Secondarily this study aims to explore factors contributing to recovery and gain insight into the cost-effectiveness of ATR management.
\end{abstract}

Methods: This multicenter prospective cohort study will include all adult ( $\geq 18$ years) patients with an ATR treated at the three main hospitals in the Northern Netherlands: University Medical Center Groningen, Martini Hospital Groningen and Medical Center Leeuwarden. All subjects will be invited for three visits at 3, 6 and 12 months post-injury. The following data will be collected: patient-reported outcome measures (PROMs), physical tests, imaging and economic questionnaires. At 3 months post-injury personal, injury, and treatment data will be collected through a baseline questionnaire and assessment of the medical file. The PROMs concern the Dutch version of the Achilles Tendon Total Rupture Score, EQ-5D-5 L, Oslo Sport Trauma Research Center Overuse Injury Questionnaire, Injury Psychological Readiness Return to Sport Scale, Tampa Scale of Kinesiophobia, Expectations, Motivation and Satisfaction questionnaire and a ranking of reasons for not returning to sport. The administered physical tests are the heel-rise test, standing dorsiflexion range of motion, resting tendon length and single leg hop for distance. Ultrasound Tissue Characterization will be used for imaging. Finally, economic data will be collected using the Productivity Cost Questionnaire and Medical Consumption Questionnaire.

Discussion: This prospective cohort study will contribute to optimal decision making in the primary treatment and rehabilitation of ATRs by providing insight into (1) ATR recovery (2) novel imaging for monitoring recovery (3) (barriers to) return to sport and (4) cost-effectiveness of management. The analysis of these data strives to give a broad insight into the recovery after ATR as well as provide data on novel imaging and costs, contributing to individualized ATR management.

Trial registration: Trialregister.nl. NTR6484. 20/06/2017. 20/07/2017.

Keywords: Achilles tendon rupture, PROM, Ultrasound tissue characterization, Prospective cohort, Multicenter, Rehabilitation, Economic, Shared-decision making

\footnotetext{
*Correspondence: o.c.dams@umcg.nl

'Department of Sport and Exercise Medicine, University of Groningen,

University Medical Center Groningen, Groningen, The Netherlands

${ }^{2}$ Department of Orthopedics, University of Groningen, University Medical

Center Groningen, Groningen, The Netherlands

Full list of author information is available at the end of the article
}

(c) The Author(s). 2019 Open Access This article is distributed under the terms of the Creative Commons Attribution 4.0 International License (http://creativecommons.org/licenses/by/4.0/), which permits unrestricted use, distribution, and reproduction in any medium, provided you give appropriate credit to the original author(s) and the source, provide a link to the Creative Commons license, and indicate if changes were made. The Creative Commons Public Domain Dedication waiver (http://creativecommons.org/publicdomain/zero/1.0/) applies to the data made available in this article, unless otherwise stated. 


\section{Background}

The Achilles tendon is the strongest and thickest tendon in the human body $[1,2]$. Despite its size, it is also the most frequently ruptured tendon. Achilles tendon rupture (ATR) usually occurs due to overloading of the tendon, often in a sport setting [2-4]. ATR has an acute presentation of severe pain, inability to bear weight, and weakness [2]; these disabilities can persist for more than 10 years after injury [5-8]. The incidence of ATR is steadily increasing globally [9-13]; this increase is most prominent in the elderly, who are participating in recreational physical activity more often than in the past [14-16].

Despite the high and increasing burden, consensus on ATR management is lacking. The American Academy of Orthopedic Surgeons (AAOS) published the only international guidelines, however these guidelines have a limited or inconclusive recommendation for the role of imaging, the choice of primary treatment, the methods of rehabilitation and the advised time to return to sport (RTS) [17]. Currently, management decisions depend mostly on the experience and perspective of the practitioner who sees the patient first [18]. Surgical and non-surgical treatment are both supported by literature [5] and the rehabilitation starts at 3 months post-injury, as recommended by the AAOS [5, 17].

Because there is conclusive evidence that outcomes after surgical and non-surgical treatment of ATRs are comparable [5], methods of rehabilitation are becoming increasingly significant [19-24]. Despite this, data on the course of the recovery after ATR are still limited, potentially resulting in suboptimal rehabilitation. Specifically, data such as psychosocial factors related to outcome (including return to sport) after ATR treatment as well as novel imaging is lacking and ATR patient continue to be burdened with a high rates of re-rupture and complications $[5,25,26]$ and unpredictable recovery and return to sport (RTS) [6, 27-29]. Several patient-related (BMI, comorbidities and athletic status) and injury-related (delay in presentation, injury etiology, gap-size) factors have a possible influence on the recovery and final outcome [26, 30-35]. However, the role of these factors on ATR recovery using multiple, comprehensive outcomes has not been analyzed. Especially because the overall difference in outcome based on primary treatment (surgical or non-surgical) is minimal [5], it is important for clinicians to individualize treatment and make evidence based decisions based on specific patient and injury-related factors.

To reach this, it is essential to enhance knowledge concerning the recovery from the patient's perspective (physical functioning, quality of life), the clinical perspective (tendon structure and strength) and societal perspective (costs and participation). Hence, this study aims to give a broad insight into the recovery after ATR as well as provide data on novel imaging and costs, thereby providing data that allows clinicians to individualize ATR management.

\section{Aims}

The primary aim of this study is to give a broad insight into the recovery after ATR. Secondarily this study aims to explore factors contributing to recovery and gain insight into the cost-effectiveness of ATR management.

\section{Methods \\ Design}

A multicenter prospective cohort study will be conducted. This study has been approved by the Medical Ethical Committee (METc) of the University Medical Center Groningen (UMCG) (METc 2017/126). This study was locally approved (local feasibility) by the medical ethical committees of the Martini Hospital Groningen (MHG) (MEC 2017-087) and Medical Center Leeuwarden (MCL) (COV 274(a)).

\section{Participants and setting}

Eligible patients are all patients with an ATR who are treated at the three largest hospitals in the Northern Netherlands: UMCG, MHG and/or MCL. Patients will be included within the first 3 months post-injury.

Inclusion criteria:

- Older than 18 years of age at the time of inclusion

- Clinically diagnosed with an ATR and treated at the UMCG, MHG and/or MCL

\section{Exclusion criteria:}

- Unable to understand written Dutch

- Physically unable to perform the tests and/or cognitively unable to complete the questionnaires

\section{Sample size calculation}

A formal sample size calculation is difficult due to the exploratory design of this cohort study as well as the lack of comparable data on ATR recovery. All eligible patients within the designated inclusion period who consent to participate will be included. Based on hospital data indicating the treatment of approximately 15 ATRs per hospital per year as well as similar studies by the research group showing a dropout of $10-20 \%$, we estimate 50 patients will be included. This number will allow us to include at least 5 independent variables in the regression analyses based on "the rule of thumb" of 10 subjects per variable (one in ten rule) [36-38]. Other studies assessing ATR recovery usually included lower patient numbers $[20,27,39,40]$. 


\section{Study procedures Recruitment}

The conducting researcher (OCD) will screen the list of patients treated at the Emergency Departments of the UMCG, MHG or MCL and contact all who have been treated for an ATR. All subjects will receive oral and written information about the study prior to giving informed consent.

\section{Data collection}

Upon consent for participation each subject will be invited for three visits: 3, 6 and 12 months post-injury for data collection. This timeframe is chosen based on the recommendations of the AAOS enabling return to work/sport within 3-6 months and the recovery phase of ATR management starting at 3 months post-injury.

\section{Measurements}

Table 1 presents an overview of the specific data collected.

\section{Demographic and lifestyle data}

A baseline questionnaire concerning personal subject data was constructed for specific use in this study. The items in this questionnaire concern biographical information (age), anthropometrics (height, weight), lifestyle factors (smoking, (level of) physical activity, work, urban/rural inhabitant), personal and family medical history including injuries and tendon complaints, injury (etiology, extent, and symptoms) and management factors during rehabilitation (physiotherapy).

\section{Medical data}

The patients' medical files will be inspected at baseline for medical history, medication, injury (etiology and extent (gap-size)) and ATR management (treatment delay, surgical or non-surgical treatment and methods, methods and length of rehabilitation, imaging applied) data. Additionally, the medical status will be monitored throughout the study period for information on injury, treatment and complications if applicable.

\section{PROMs}

The Achilles Tendon Total Rupture Score (ATRS) is a questionnaire used to measure outcome related to symptoms and physical activity after treatment in patients with an ATR [41]. It consists of ten questions each concerning ten points. This instrument is a valid and reliable method of measuring outcome in ATR patients [41]. It is a self-administered instrument with high clinical applicability, and the score can be used to measure the outcome related to symptoms and physical activity, after treatment in patients with a ATR. In this study the Dutch version will be used (ATRS-NL) which is found to be valid and reliable [42]. In the Dutch version the maximum score (=maximum disability) $=100$. This

Table 1 Measurements per visit

\begin{tabular}{|c|c|c|c|c|}
\hline Data Category & Outcome measure/tool ${ }^{a}$ & $\begin{array}{l}\text { Month } \\
3\end{array}$ & Month 6 & Month 12 \\
\hline $\begin{array}{l}\text { Demographic and } \\
\text { Lifestyle }\end{array}$ & Baseline questionnaire & $x$ & & \\
\hline Medical & Medical file & $x$ & $x$ & $x$ \\
\hline \multirow[t]{7}{*}{ PROMs } & ATRS-NL ${ }^{b}$ questionnaire & $x$ & $x$ & $x$ \\
\hline & EQ-5D-5 L questionnaire & $x$ & $x$ & $x$ \\
\hline & OSTRC ${ }^{C}$-Overuse questionnaire & $x$ & $x$ & $x$ \\
\hline & I-PRRS $^{\mathrm{d}}$ & $x$ & $x$ & $x$ \\
\hline & $\mathrm{TSK}^{\mathrm{e}}$ & $x$ & $x$ & $x$ \\
\hline & $\begin{array}{l}\text { Expectations, motivations and satisfaction } \\
\text { questionnaire }\end{array}$ & $x$ & $\begin{array}{l}\text { X (only satisfaction and } \\
\text { motivation) }\end{array}$ & $\begin{array}{l}\text { X (only satisfaction and } \\
\text { motivation) }\end{array}$ \\
\hline & Reasons for not RTS & & $x$ & $x$ \\
\hline \multirow[t]{4}{*}{ Physical tests } & Heel-rise test & $x$ & $x$ & $x$ \\
\hline & Ankle dorsiflexion $\mathrm{ROM}^{\mathrm{f}}$ & $x$ & $x$ & $x$ \\
\hline & Tendon length & $x$ & $x$ & $x$ \\
\hline & Single leg hop for distance & & & $x$ \\
\hline Imaging & $U_{T C}^{g}$ & $x$ & $x$ & $x$ \\
\hline \multirow{2}{*}{$\begin{array}{l}\text { Economic } \\
\text { questionnaires }\end{array}$} & $i P C Q^{h}$ & $x$ & $x$ & $x$ \\
\hline & iMCQ' & $x$ & $x$ & $x$ \\
\hline
\end{tabular}

a detailed description of the specific outcome measures/tools is given in the subsection measurements. ${ }^{b}$. Dutch version of the Achilles Tendon Total Rupture Score ${ }^{c}$. Oslo Sports Trauma Research Center ${ }^{d}$. Injury Psycological Readiness to Return to Sport ${ }^{\mathrm{e}}$ Tampa Scale of Kinesiophobia ${ }^{\mathrm{f}}$. Range of motion ${ }^{\mathrm{g}}$. Ultrasound Tissue Characterization ${ }^{\mathrm{h}}$. Productivity Cost Questionnaire ${ }^{\mathrm{j}}$. Medical Consumption Questionnaire 
measurement will serve as the primary outcome in the analyses.

The Dutch version of the EQ-5D-5L is the most commonly used generic questionnaire to measure quality of life. It encompasses physical, mental, emotional and social functioning. This questionnaire is used to make decisions in cost-effectiveness analyses [43]. The EQ-5D-5 L is scored on a 5-point Likert scale. The result score is a 5-number index score, reflecting the individual's health-profile. This score can be converted to a total score between 0 (death) and 1 (completely healthy).

The OSTRC Overuse Injury Questionnaire is a 5-question tool used to estimate the burden of injury with respect to RTS, specifically with respect to knee, shoulder or lower back injury. This questionnaire has been found valid [44]. We have modified the Dutch version of this questionnaire to pertain to Achilles tendon injury. This questionnaire will be used to determine the effect of injury on the RTS.

The Injury Psychological Readiness Return to Sport (I-PRRS) Questionnaire assesses an athlete's psychological readiness to RTS after injury [45]. The I-PRRS is a valid and reliable tool for measuring psychological readiness to RTS. The questionnaire consists of six items that are each scored on a 100-point scale. The total score ranges from 0 to 60 and consists of the sum the six items, divided by 10. A higher score implies greater confidence to RTS. We translated the I-PRRS into Dutch following international guidelines [46, 47].

The Tampa Scale of Kinesiophobia (TSK) measures fear of re-injury due to movement and physical activity. It contains 17 items scored on a four-point Likert scale regarding the subjective experience of the injury and physical activity. The sum of the items results in a score between 17 and 68, where 68 indicates a high level of fear [48]. For this study, the modified Dutch version, adapted for tendon injuries will be used [49]. This questionnaire has been validated in Dutch for measurement of fear of movement/reininjury, although not in an ATR population [49].

A questionnaire concerning expectations, motivation and satisfaction with regard to RTS was constructed. This questionnaire contains 15 questions divided over three dimensions: Expectations (9 questions), Motivation (3 questions) and Satisfaction (3 questions) based on the questionnaire by Sonneson \& Ardern (2016) [50]. The questionnaire was designed specifically for use in this study.

A questionnaire concerning reasons for not RTS will be administered. The questionnaire consists of a ranking scale used in prior psychosocial RTS studies after Anterior Cruciate Ligament (ACL) injury [51]. The scale has been translated to Dutch and we modified it to pertain to Achilles tendon injury. The scale was based on the previous reported data on RTS after ACL injury [51]. Patients who reported that they had not returned to their preinjury activity were asked to rank the following reasons for not returning from most important to least important: 'poor tendon function,' 'do not trust the tendon, 'fear getting a new injury', 'team or training has changed,' 'family commitments', 'work commitments' and 'other reasons'.

\section{Physical tests}

Endurance will be assessed with the single leg heel-rise test. This test is a reliable measure of endurance in patients after ATR [52]. With this test patients are instructed to stand on one foot on a 60 degree incline board and perform as many heel-rises as possible. Figure 1 shows the heel-rise test setup. Patients are allowed to have 2 fingertips per hand against the wall for balance, and will perform the rises at a rate of 30 heel rises per minute as guided by a metronome. For each heel-rise they are instructed to go as high as possible and then lower the heel to the starting position. The test will be terminated when the patients stop, cannot maintain the frequency, or cannot perform a proper heel rise [53]. The heel-rise count of the injured foot will be compared to the contralateral (uninjured) foot. The outcome is calculated as the percentage of the heel-rise test count of the ATR-affected side compared to the contralateral (uninjured) limb. The unaffected side is evaluated first.

The tendon length of both the injured and uninjured Achilles tendon will be measured by determining the resting tension on the ankle (the resting plantarflexion with the patients foot prone on an examination table with the feet hanging over the edge). The degree of plantarflexion represents the tendon length [54]. Resting plantarflexion will be measured by using goniometer placed along the lateral border of the foot as described by Ecker et al. [54], this method has been described previously and determined to correlate to muscle strength.

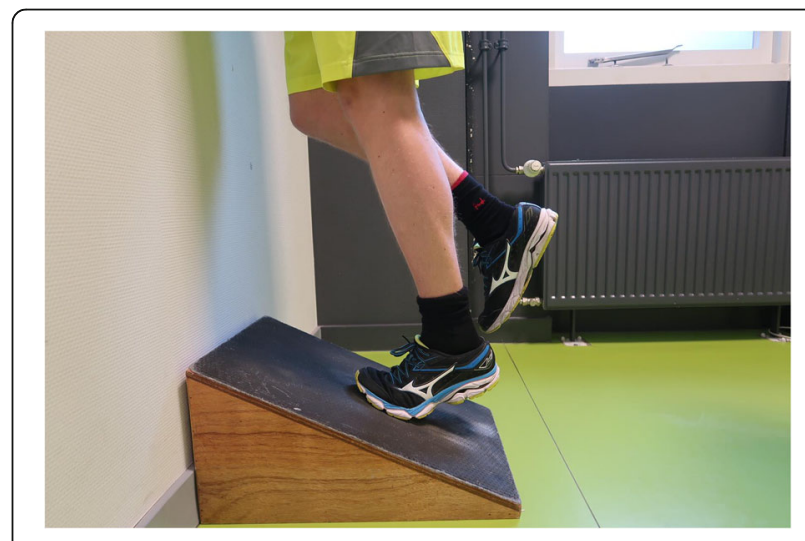

Fig. 1 Heel-rise test 
The outcome concerns the difference in resting prone plantarflexion between the injured and contralateral foot.

Maximum standing dorsiflexion range of motion (ROM) will be measured with a goniometer with the patient standing. This method has been shown to have good reliability $[53,55]$. Care will be taken to place the foot in a subtalarneutral position. The proximal arm of the goniometer will be aligned with the midline of the fibula, the fulcrum with the lateral malleolus, and the distal arm parallel to the fifth metatarsal. The ROM will be compared to the contralateral (healthy) foot.

The entire lower extremity will be tested with the single leg hop for distance. In this test the patient is instructed to stand on one leg and to hop once as far forward as possible, landing only on the same leg. The single leg hop is a reliable test for the function of the lower extremity [56]. The distance from the tip of the patient's great toe at the starting position to the tip of the patient's great toe in the landing position is recorded with a tape measure. This test will only be performed at 12 months post-injury. Each leg will be tested three times, and the mean distance hopped over the three repetitions is used for the analysis. The unaffected side is evaluated first.

\section{Imaging}

Ultrasound Tissue Characterization (UTC) is a novel device that can tomographically visualise and accurately quantify tendon structure in three planes. The device has a 7-10 $\mathrm{mHZ}$ transducer that moves automatically over tendons and makes transverse recordings over regular intervals of $0.2 \mathrm{~mm}$ (Fig. 2) [57]. Operator-dependent variables like transducer tilt, angle, gain and depth are standardized in this scanning method. Tendon structure is quantified via the analysis of the Achilles tendon based on echo-type stability. UTC quantifies tendon structure in four distinct types (I-IV) depending on the amount of

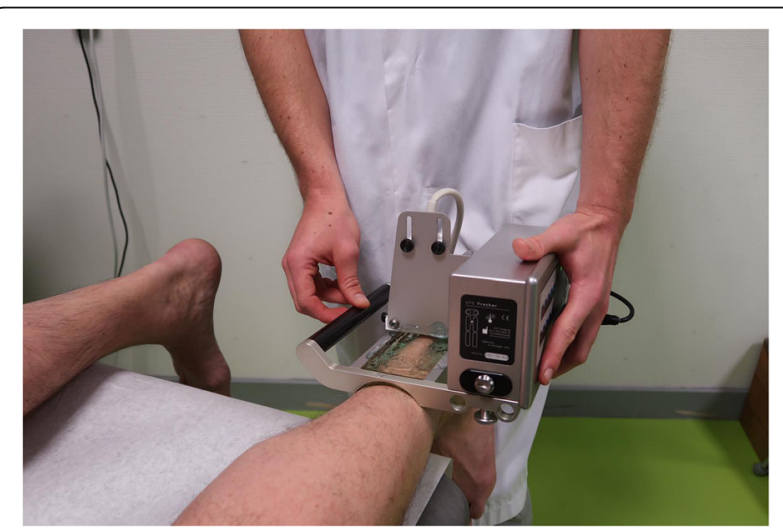

Fig. 2 UTC device (probe and tracker) [59] fibrillar disorganization and tendon integrity. Echo-type I is the most stable echo pattern and echo-type IV is the least stable echo pattern [57]. The entire tendon will be analyzed. The outcome consists of the percentage of the four different echo-types. This quantification of tendon structure provides the possibility to monitor subtle changes [57]. The UTC has not been used ATR in patients, but has shown potential as a monitoring device in the evaluation of tendinopathy patients and assessing the quality of (Achilles) tendon structure [57].

\section{Economic questionnaires}

For productivity costs the the institute for Medical Technology Assessment (iMTA) Productivity Cost Questionnaire (iPCQ) will be administered. The iPCQ is a specially constructed Dutch questionnaire designed to measure the indirect costs associated with treatment. It contains three modules (absenteism, presenteeism and productivity losses related to and unpaid work) designed to measure all of the indirect costs associated with medical treatment [58].

For direct medical costs the iMTA Medical Consumption Questionnaire (iMCQ) will be administered. The iMCQ is a specially constructed Dutch questionnaire designed to measure the direct costs associated with treatment. The questions concern ambulance and emerency room use, visits to general practice and the hospital and use of physiotherapty and alternative (homeopathy, acupuncture, e.g.) care. The iMTA costing tool handbook will be used to to collect reference value for treatment costs in the Netherlands.

\section{Statistical analysis}

IBM SPSS Statistics for Windows software (Version 23.0, Armonk, NY: IBM Corp.) will be used for all statistical data analyses. Descriptive statistics (frequencies, means and standard deviations, etc.) will be used to describe all data. Spearman's correlation coefficients will be used to describe association between data. Statistical significance is defined as $P<0.05$.

The following are the planned statistical analyses per aim:

\section{Primary aim:}

- Generalized estimating equations (GEEs) will be conducted to assess the outcomes over time: 3,6 , and 12 months.

Secondary aim:

- Linear regression analyses will be performed to assess factors predictive of Achilles tendon function. First, univariate analysis will be performed as a hypothesis-generating analysis model with ATRS-NL score $(0-100)$ as dependent variable and a predicting factor as independent factor. Factors showing a 
relation with the outcome measure with a $p$-value $<0.20$ will be included in a multiple linear regression analysis. Additionally, binary logistic regression will be used to determine the factors associated with returning to the pre-injury sport or recreational activity. Return to the pre-injury activity (yes or no) is the outcome variable.

- The Incremental Cost-effectiveness Ratio (ICER) $(=\Delta$ Cost of treatment/ $\Delta$ Effect of treatment) associated with each unique treatment modality will be calculated. The ICER is calculated by taking the difference in costs associated with each possible treatment modality and its alternative (e.g. physiotherapy vs. no physiotherapy) and dividing by the difference in effect. Costs are calculated by adding the direct (e.g. cost of treatment from iMCQ questionnaire) and indirect (e.g. loss of work, from iPCQ questionnaire) costs associated with each possible treatment. Effect consists of the EQ-5D-5 L and/or ATRS-NL outcomes. The cost-effectiveness of ATR management options will herewith be determined at 3, 6, and 12 months post injury.

\section{Discussion}

There is an increasing incidence of ATR, and numerous long term impairments are reported. Despite several randomized controlled trials comparing various methods of primary treatment, clinical treatment and rehabilitation guidelines are still lacking. This multicenter prospective cohort study focuses specifically on the rehabilitation phase. This study will contribute to the primary treatment and rehabilitation of ATRs by providing insight into (1) ATR recovery, (2) novel imaging for monitoring recovery, (3) (barriers to) RTS and (4) cost-effectiveness of management. These data will provide a broad understanding of ATR recovery as well as provide data on novel imaging and costs, thereby providing knowledge for clinicians in shared decision making and individualizing ATR management.

\footnotetext{
Abbreviations

AAOS: American Academy of Orthopedic Surgeons; ACL: Anterior Cruciate Ligament; ATR: Achilles tendon rupture; ATRS: Achilles Tendon Total Rupture Score; GEE: Generalized estimating equation; ICER: Incremental Costeffectiveness Ratio; iMCQ: Medical Consumption Questionnaire; iMTA: Institute for Medical Technology Assessment; iPCQ: Productivity Cost Questionnaire; I-PRRS: Injury psychological readiness return to sport scale; MCL: Medical Center Leeuwarden; MHG: Martini Hospital Groningen; OSTRC: Oslo Sport Trauma Research Center; PROMs: Patient-reported outcome measures; ROM: Range of motion; RTS: Return to sport; TSK: Tampa Scale of Kinesiophobia; UMCG: University Medical Center Groningen; UTC: Ultrasound Tissue Characterization
}

\section{Acknowledgements}

Not applicable

\section{Funding}

This study was not externally funded.

\section{Availability of data and materials}

The datasets that will be generated during the current study are available from the corresponding author on reasonable request.

\section{Authors' contributions}

Scientific idea: OCD, IvdAS, RLD, KWW, IHFR, JZ; Project planning: OCD, IvdAS, RLD, KWW, EB, TMVR, AVM, WPZ, IHFR, JZ; Manuscript writing: OCD, IVdAS, RLD, KWW, EB, TMVR, AVM, WPZ, IHFR, JZ; Manuscript revision: OCD, IVdAS, RLD, KWW, EB, TMVR, AVM, WPZ, IHFR, JZ; All authors approved the final manuscript.

\section{Ethics approval and consent to participate}

The study has been approved by the Medical Ethics Committee of the University Medical Center Groningen (METc 2017/126) and locally approved by the ethical committees of the Martini Hospital Groningen (MEC 2017-087) and Medical Center Leeuwarden (COV 274(a)) Participants are included after receiving written and oral information and providing signed informed consent.

Consent for publication

Not applicable.

\section{Competing interests}

The authors declare that they have no competing interests.

\section{Publisher's Note}

Springer Nature remains neutral with regard to jurisdictional claims in published maps and institutional affiliations.

\section{Author details}

${ }^{1}$ Department of Sport and Exercise Medicine, University of Groningen, University Medical Center Groningen, Groningen, The Netherlands. 2Department of Orthopedics, University of Groningen, University Medical Center Groningen, Groningen, The Netherlands. ${ }^{3}$ Department of Trauma Surgery, University of Groningen, University Medical Center Groningen, Groningen, The Netherlands. ${ }^{4}$ Department of Surgery, Martini Hospital, Groningen, The Netherlands. ${ }^{5}$ Department of Orthopaedic Surgery, Martini Hospital, Groningen, The Netherlands. ${ }^{6}$ Department of Surgery, Medical Center Leeuwarden, Leeuwarden, The Netherlands. ${ }^{7}$ Department of Orthopaedic Surgery, Medical Center Leeuwarden, Leeuwarden, The Netherlands.

Received: 19 March 2018 Accepted: 28 January 2019

Published online: 11 February 2019

\section{References}

1. Freedman BR, Gordon JA, Soslowsky LJ. The Achilles tendon: fundamental properties and mechanisms governing healing. Muscles Ligaments Tendons J. 2014:4:245-55. https://doi.org/10.11138/mltj/2014.4.2.245.

2. Maffulli N. Current concepts review - rupture of the Achilles tendon*. J Bone Joint Surg Am. 1999;81:1019-36.

3. Raikin SM, Garras DN, Krapchev PV. Achilles tendon injuries in a United States population. Foot Ankle Int. 2013;34:475-80. https://doi.org/10.1177/ 1071100713477621.

4. Houshian S, Tscherning T, Riegels-Nielsen P. The epidemiology of achilles tendon rupture in a Danish county. Injury. 1998;29:651-4.

5. Holm C, Kjaer M, Eliasson P. Achilles tendon rupture - treatment and complications: a systematic review. Scand J Med Sci Sports. 2014;25:e1-e10. https://doi.org/10.1111/sms.12209.

6. Horstmann T, Lukas C, Merk J, Brauner T, Mündermann A. Deficits 10-years after Achilles tendon repair. Int J Sports Med. 2012;33:474-9.

7. Lantto I, Heikkinen J, Flinkkila T, Ohtonen P, Kangas J, Siira P, et al. Early functional treatment versus cast immobilization in tension after Achilles rupture repair: results of a prospective randomized trial with 10 or more years of follow-up. Am J Sports Med. 2015.

8. Pajala A, Kangas J, Siira P, Ohtonen P, Leppilahti J, A P, et al. Augmented compared with nonaugmented surgical repair of a fresh total achilles tendon rupture: A prospective randomized study. J Bone Jt Surg Ser A. 2009;91:1092-100. https://doi.org/10.2106/JBJS.G.01089.

9. Maffulli N, Waterston SW, Squair J, Reaper J, Douglas AS. Changing incidence of Achilles tendon rupture in Scotland: a 15-year study. Clin J Sport Med. 1999; 9:157-60. https://doi.org/10.1097/00042752-199907000-00007. 
10. Möller A, Astron M, Westlin N. Increasing incidence of Achilles tendon rupture. Acta Orthop Scand. 1996;67:479-81.

11. Leppilahti J, Puranen J, Orava S. Incidence of Achilles tendon rupture. Acta Orthop Scand. 1996;67:277-9.

12. Nyyssönen $T$, Lüthje $P$, Kröger $H$. The increasing incidence and difference in sex distribution of Achilles tendon rupture in Finland in 1987-1999. Scand J Surg. 2008;97:272-5.

13. Ganestam A, Kallemose T, Troelsen A, Barfod KW. Increasing incidence of acute Achilles tendon rupture and a noticeable decline in surgical treatment from 1994 to 2013. A nationwide registry study of 33,160 patients. Knee Surg Sports Traumatol Arthrosc. 2016;24:3730-7.

14. Erickson BJ, Cvetanovich GL, Nwachukwu BU, Villarroel LD, Lin JL, Bach BR, et al. Trends in the Management of Achilles Tendon Ruptures in the United States Medicare population, 2005-2011. Orthop J Sport Med. 2014;2: 232596711454994. https://doi.org/10.1177/2325967114549948.

15. Ho G, Tantigate D, Kirschenbaum J, Greisberg JK, Vosseller JT. Increasing age in Achilles rupture patients over time. Injury. 2017:48:1701-9.

16. Huttunen TT, Kannus P, Rolf C, Fellander-Tsai L, Mattila VM. Acute achilles tendon ruptures: incidence of injury and surgery in Sweden between 200 and 2012. Am J Sports Med. 2014;42:2419-23.

17. Chiodo CP, Glazebrook M, Bluman EM, Cohen BE, Femino JE, Giza E, et al. American Academy of Orthopaedic Surgeons clinical practice guideline on treatment of Achilles tendon rupture. J Bone Joint Surg Am. 2010;92-A: 2466-8. https://doi.org/10.2106/JBJS.15.01494.

18. Dams OC, van den Akker-Scheek I, Diercks RL, Wendt KW, Zwerver J, Reininga IHF. Surveying the management of Achilles tendon ruptures in the Netherlands: lack of consensus and need for treatment guidelines. Knee Surg Sports Traumatol Arthrosc. 2018:1-11. https://doi.org/10.1007/s00167018-5049-5.

19. Mark-Christensen T, Troelsen A, Kallemose T, Barfod KW. Functional rehabilitation of patients with acute Achilles tendon rupture: a meta-analysis of current evidence. Knee Surg Sports Traumatol Arthrosc. 2016;24:1852-9. https://doi.org/10.1007/s00167-014-3180-5.

20. Mccormack R, Bovard J, Mccormack RG. Early functional rehabilitation or cast immobilisation for the postoperative management of acute Achilles tendon rupture? A systematic review and meta-analysis of randomised controlled trials. Br J Sport Med. 2015;49:1329-35.

21. Hutchison AM, Topliss C, Beard D, Evans RM, Williams P. The treatment of a rupture of the achilles tendon using a dedicated management programme. Bone Joint J. 2015:97-B:510-5.

22. Brumann M, Baumbach SF, Mutschler W, Polzer H. Accelerated rehabilitation following Achilles tendon repair after acute rupture - development of an evidence-based treatment protocol. Injury. 2014;45:1782-90. https://doi.org/ 10.1016/j.injury.2014.06.022

23. Maffulli N. Immediate weight-bearing is not detrimental to operatively or conservatively managed rupture of the Achilles tendon. Aust J Physiother. 2006;52.

24. Wang KC, Cotter EJ, Cole BJ, Lin JL. Rehabilitation and return to play following Achilles tendon repair. Oper Tech Sports Med. 2017;25:214-9. https://doi.org/10.1053/j.otsm.2017.07.009.

25. Metz R, van der Heijden GJMG, Verleisdonk E-JMM, Kolfschoten N, Verhofstad MHJ, van der Werken C. Effect of complications after minimally invasive surgical repair of acute achilles tendon ruptures: report on 211 cases. Am J Sports Med. 2011;39:820-4.

26. Carmont MR, Silbernagel KG, Edge A, Mei-Dan O, Karlsson J, Maffulli N. Functional outcome of percutaneous achilles repair: improvements in achilles tendon total rupture score during the first year. Orthop J Sport Med. 2013;1:2325967113494584

27. Zellers JA, Carmont MR, Grävare SK. Return to play post-Achilles tendon rupture: a systematic review and meta-analysis of rate and measures of return to play. Br J Sports Med. 2016;50:1325-32. https://doi.org/10.1136/ bjsports-2016-096106.

28. Trofa DP, Miller JC, Jang ES, Woode DR, Greisberg JK, Vosseller JT. Professional athletes' return to play and performance after operative repair of an Achilles tendon rupture. Am J Sports Med. 2017;45:2864-71. https:// doi.org/10.1177/0363546517713001.

29. Fox G, Gabbe BJ, Richardson M, Oppy A, Page R, Edwards ER, et al. Twelvemonth outcomes following surgical repair of the Achilles tendon. Injury. 2016:47:2370-4.

30. Kvist M. Achilles tendon injuries in athletes. Sports Med. 1994;18:173-201. https://doi.org/10.2165/00007256-199418030-00004.
31. Maffulli N, Ajis A. Management of Chronic Ruptures of the Achilles tendon. Bone Joint Surg Am. 2008;90:1348-60. https://doi.org/10.2106/JBJS.G.01241.

32. Lawrence JE, Nasr P, Fountain DM, Berman L, Robinson AHN. Functional outcomes of conservatively managed acute ruptures of the Achilles tendon. Bone Joint J. 2017;99-B:87-93.

33. Claessen FMAP, de Vos RJ, Reijman M, Meuffels DE. Predictors of primary Achilles tendon ruptures. Sports Med. 2014;44:1241-59.

34. Carmont MR, Zellers JA, Brorsson A, Olsson N, Nilsson-Helander K, Karlsson J, et al. Functional outcomes of achilles tendon minimally invasive repair using 4- and 6-strand nonabsorbable suture: a cohort comparison study. Orthop J Sport Med. 2017:5:2325967117723347.

35. Carmont MR, Grävare Silbernagel K, Brorsson A, Olsson N, Maffulli N, Karlsson J. The Achilles tendon resting angle as an indirect measure of Achilles tendon length following rupture, repair, and rehabilitation. Asia Pacific J Sport Med Arthrosc Rehabil Technol. 2015:2:49-55.

36. Harrell FE, Lee KL, Califf RM, Pryor DB, Rosati RA. Regression modelling strategies for improved prognostic prediction. Stat Med. 1984;3:143-52.

37. Harrell FE, Lee KL, Mark DB. Multivariable prognostic models: issues in developing models, evaluating asumptions and adequacy, and measuring and reducing error. Stat Med. 1996;15:361-87.

38. Peduzzi $P$, Concato J, Kemper $E$, Holford TR, Feinstem AR. A simulation study of the number of events per variable in logistic regression analysis. J Clin Epidemiol. 1996:49:1373-9.

39. Huang J, Wang C, Ma X, Wang X, Zhang C, Chen L. Rehabilitation regimen after surgical treatment of acute Achilles tendon ruptures: a systematic review with meta-analysis. Am J Sport Med. 2015;43:1008-16. https://doi. org/10.1177/0363546514531014.

40. Dams OC, Reininga IHF, Gielen JL, van den Akker-Scheek I, Zwerver J. Imaging modalities in the diagnosis and monitoring of Achilles tendon ruptures: a systematic review. Injury. 2017;48:2383-99.

41. Nilsson-Helander K, Thomeé R, Silbernagel KG, Thomeé P, Faxén E, Eriksson $\mathrm{BI}$, et al. The Achilles tendon Total rupture score (ATRS): development and validation. Am J Sports Med. 2007;35:421-6.

42. Opdam KTM, Zwiers R, Wiegerinck Jl, Kleipool AEB, Haverlag R, Goslings JC, et al. Reliability and validation of the Dutch Achilles tendon Total rupture score. Knee Surg Sports Traumatol Arthrosc. 2016;26(3):1-7.

43. Lamers LM, Stalmeier PFM, McDonnell J, Krabbe PFM, Van Busschbach JJ. Kwaliteit van leven meten in economische evaluaties : het Nederlands EQ5D-tarief. Ned Tijdschr Geneeskd. 2005;149:5

44. Clarsen B, Myklebust G, Bahr R. Development and validation of a new method for the registration of overuse injuries in sports injury epidemiology: the Oslo sports trauma research Centre (OSTRC) overuse injury questionnaire. $\mathrm{Br} J$ Sports Med. 2013;47:495-502. https://doi.org/10.1136/bjsports-2012-091524.

45. Glazer DD. Development and preliminary validation of the injury-psychological readiness to return to sport (I-PRRS) scale. J Athl Train. 2009:44:185-9.

46. Beaton DE, Bombardier C, Guillemin F, Ferraz MB. Guidelines for the Process of Cross-Cultural Adaptation of Self-Report Measures. Spine (Phila Pa 1976). 2000;25:3186-91. https://doi.org/10.1097/00007632-200012150-00014.

47. Slagers AJ, Reininga IHF, Geertzen JHB, Zwerver J, van den Akker-Scheek I. Translation, cross-cultural adaptation, validity, reliability and stability of the Dutch injury - psychological readiness to return to sport (I-PRRS-NL) scale. J Sports Sci. 2018. https://doi.org/10.1080/02640414.2018.1540101.

48. Kori SH, Miller RP, Todd DD. Kinesiophobia: a new view of chronic pain behavior. Pain Manag. 1990;35:35-43.

49. Vlaeyen JWS, Kole-Snijders AMJ, Boeren RGB, van Eek H. Fear of movement/ (re)injury in chronic low back pain and its relation to behavioral performance. Pain. 1995;62:363-72.

50. Sonesson S, Kvist J, Ardern C, Österberg A, Silbernagel KG. Psychological factors are important to return to pre-injury sport activity after anterior cruciate ligament reconstruction: expect and motivate to satisfy. Knee Surg Sports Traumatol Arthrosc. 2016;25(5):1-10.

51. Ardern CL, Osterberg A, Tagesson S, Gauffin H, Webster KE, Kvist J. The impact of psychological readiness to return to sport and recreational activities after anterior cruciate ligament reconstruction. Br J Sports Med. 2014;48:1613-9.

52. Moller M, Lind K, Styf J, Karlsson J. The reliability of isokinetic testing of the ankle joint and a heel-raise test for endurance. Knee Surg Sports Traumatol Arthrosc. 2005;13:60-71. https://doi.org/10.1007/s00167-003-0441-0.

53. Silbernagel KG, Nilsson-Helander K, Thomeé R, Eriksson BI, Karlsson J, K. GS, et al. A new measurement of heel-rise endurance with the ability to detect functional deficits in patients with Achilles tendon rupture, Knee Surg Sports Traumatol Arthrosc. 2010;18:258-64. https://doi.org/10.1007/s00167-009-0889-7. 
54. Ecker TM, Bremer AK, Krause FG, Müller T, Weber M. Prospective use of a standardized nonoperative early Weightbearing protocol for Achilles tendon rupture: 17 years of experience. Am J Sports Med. 2016;44:1004-10. https:// doi.org/10.1177/0363546515623501.

55. Ekstrand J, Wiktorsson M, Oberg B, Gillquist J. Lower extremity goniometric measurements: a study to determine their reliability. Arch Phys Med Rehabil. 1982;63:171-5

56. Bolgla LA, Keskula DR. Reliability of lower extremity functional performance tests. J Orthop Sports Phys Ther. 1997;26:138-42. https://doi.org/10.2519/ jospt.1997.26.3.138.

57. van Schie HTM, de Vos RJ, de Jonge S, Bakker EM, Heijboer MP, Verhaar JAN, et al. Ultrasonographic tissue characterisation of human Achilles tendons: quantification of tendon structure through a novel non-invasive approach. $\mathrm{Br}$ Sports Med. 2010;44:1153-9. https://doi.org/10.1136/bjsm.2009.061010.

58. Bouwmans C, Krol M, Severens H, Koopmanschap M, Brouwer W, Van Roijen LH. The iMTA productivity cost questionnaire: a standardized instrument for measuring and valuing health-related productivity losses. Value Heal. 2015; 18:753-8.

59. van Ark M, Docking SI, van den Akker-Scheek I, Rudavsky A, Rio E, Zwerver J, et al. Does the adolescent patellar tendon respond to 5 days of cumulative load during a volleyball tournament? Scand J Med Sci Sport. 2016;26:189-96.

Ready to submit your research? Choose BMC and benefit from:

- fast, convenient online submission

- thorough peer review by experienced researchers in your field

- rapid publication on acceptance

- support for research data, including large and complex data types

- gold Open Access which fosters wider collaboration and increased citations

- maximum visibility for your research: over $100 \mathrm{M}$ website views per year

At $\mathrm{BMC}$, research is always in progress.

Learn more biomedcentral.com/submissions 